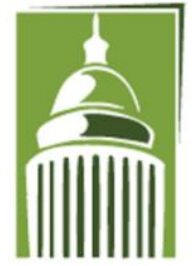

A R F
Global Proceedings Repository

American Research Foundation

ISSN 2476-017X

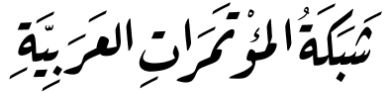

http://arab.kmshare.net/

Available online at http://proceedings.sriweb.org/akn/

\section{AASRC-ARF JOINT INTERNATIONAL ACADEMIC CONGRESS ON POLITICS, ENGINEERING, SOCIOLOGY, INFORMATION, HEALTH \& MEDICAL, EDUCATION AND COMMUNICATION}

25-26 October, 2017

Istanbul Aydın University, Istanbul

المؤتمر الكاديمي الدولي الثامن عشر - في رحاب جامعة اسطنبول ايدن | 25- 26 اكتوبر 2017 اسطنبول - تركيا

\title{
Total Physical Response in Teaching English Foreign Language for Iraqi Slow Learners
}

\author{
Asst.Prof. Dr. Baan Jafar Sadiq \\ Baghdad University/ College of Physical Education and Sciences Sport for Women \\ Banjaafar_dr@yahoo.com.
}

\begin{abstract}
The research aims to investigate experimentally total physical response in teaching EFL on a sample of slow learners. The sample of the research is 3 Down syndrome children from 3-5 years. Total physical response asa method is not new but the new is teaching Down syndrome learners English foreign language in Iraq. Down syndrome children have some delete in production skill.Therefore, the challenge is to teach Down syndrome children English Language through TPR method, TPR focused on listening rather than production which is necessary with the sample of the research. It has hypothesized that there is no significant differences among the sample of the research in learning English through TPR. The research has applied observations as a tool of collecting the data. The results have showed amazing developing in acquiring English foreign language. The sample could response and product English words although they could not produce Arabic words as much as they could in English. Thus, the null hypothesis of the research
\end{abstract}




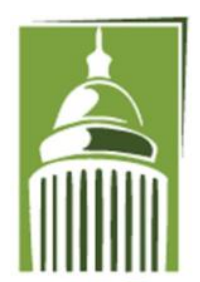

ARF

\section{Global Proceedings Repository \\ American Research Foundation}

ISSN 2476-017X

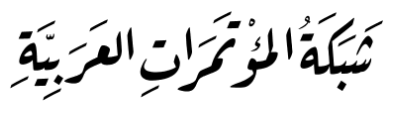

http://arab.kmshare.net/

Available online at http://proceedings.sriweb.org/akn/

is neglected and the research has recommended teaching the slow learners and Down syndrome learners English language through this method.

\section{Section One: Introduction of the Research}

\subsection{The Problem and Its Significance}

Listening comprehension had been neglected with regard to its place in foreign language teaching methodology and the development of materials and techniques for use in the classroom. But the status of listening began to change from neglect to important skill (Murcia, 2001:67-69).

For many years, listening skills didnot receive priority in language teaching. Until recently,this position has been replaced by an active interest in the role of listening comprehension in foreign language acquisition. Listening skills become fashionable again in 1980s by Krashen's idea and Asher's (1988) Total Physical Response. They believed that foreign language is learned most effectively in early stages if the pressure for production is taken off the learners (Richards \&Renandya:2002:235-238).

Down syndrome children's language development is simply delayed at first. Up to the age of 4 , their language age is consistent with their mental age. A child with Down's syndrome may show greater abilities in their cognition than in linguistics ability (Harley, 2008: 81).Thus, the research has applied TPRmethods in teaching English foreign language while most methods emphasized the production skills and speaking as the most important skill in teaching. Also, Down Syndrome children are good imitators. The research applied this method because as (Sciarini\& Steinberg, 2006) mentioned speech understanding precedes speech production in this method.

The problem of the research lies that slow learners in Iraq specially Down Syndrome Children did not receive public education in English Foreign language. Teachers and educators have waited until they become competence well in Arabic Language. Although, they are three types of down syndrome e.g mild, mediate, and sever, the mild type can learn with some difficulties.

Also, the most important problem lies that slow learners are neglected in teaching English language from two important branches that they should deal with this problem (Special Education and Methods of Teaching English Foreign Languages). The curriculum that make from Special Education of slow learners are focused on Arabic, simple math and personal care only. While the Methods of Teaching English as Foreign Language's curriculum teaches only the normal schools. Also, the slow learners have special class in each four schools, they begin their learning at age (6-9) years. If the child has successfully passedfour stages he/ she might be back to normal class. Therefore, as a matter of fact the slow learners have continues difficulties in learning so they failed in Iraqi schools. Most of them stay at home as neglected members of Iraqi society. Thus, researchers and educators should investigate more and put the right solutions for slow learners.

\subsection{Aims of the Study}




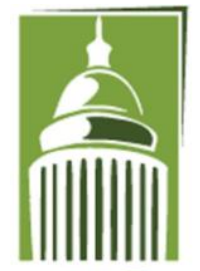

ARF

\section{Global Proceedings Repository \\ American Research Foundation}

ISSN 2476-017X

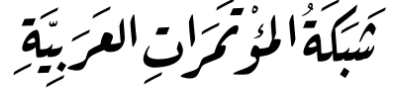

http://arab.kmshare.net/

Available online at http://proceedings.sriweb.org/akn/

The current research aims at investigating the effect of physical total response in teaching English Foreign for Iraqi slow learners.

\subsection{Hypothesis of the study}

The following null hypothesis will be tested:

There are no statistically significant differences in teaching English foreign language for Iraqi slow learners in the experimental group students who are taught EFL by using total physical responses.

\subsection{Limits of the study}

The following are the major limits of the present research:

1-The sample of the research are limited for teaching EFL.

2- Iraqi slow learners have be the concern of this research; and

3-Total physical responses in teaching EFL have be the concern of this research .

\subsection{Value of the Study}

The research might be valuable for Iraqi Ministry of Education because it sheds a light to slow learners of Iraqi society which are neglected from society, teachers, special education, Methods of teaching EFL and curriculum designers. The research might be made some contribution in teaching Iraqi slow learners which are not received any academic teaching in English foreign language.

\subsection{Definition of Basic Terms}

\subsubsection{Total Physical Response (TPR)}

It is a method of teaching built around the coordination of speech and action (Richards \& Rodgers, 2001:73).

Brown (2007:391) defines it as "a language teaching method relying on physical or kinesthetic movement accompanied by language practice".

It is a method of language teaching in which learners listen to instructions in foreign language, and carry out a sequence of physical action (Nunan,1999:316)

\subsubsection{Slow Learners}

The term slow learner is used to identify students who are seen as learning differently or having learning difficulties comes from a widespread institutional phenomenon (Williamson \& Paul, 2012: 93).

slow learner refers to any students who were seen as struggling with curriculum as well a more specific term used to describe students who were thought to be the largest subgroup of persons who fell into the category we now call mild to moderately intellectually disabled (Reynolds \& Fletcher-Janzen, 2006 cited in Ibid).

Currently, the slow learner label is often used to frame students whose Intelligence Quotients the low average level I.Q. score of between 75 and 90(King, 2006: 2-3). 


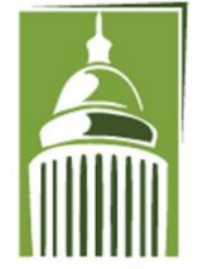

ARF

\section{Global Proceedings Repository \\ American Research Foundation}

ISSN 2476-017X

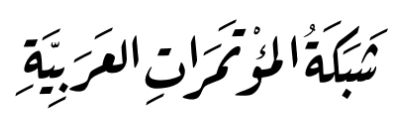

http://arab.kmshare.net/

Available online at http://proceedings.sriweb.org/akn/

\subsection{The Procedures of the Research}

The following procedures will be undertaken in order to achieve the purpose of this research:

1- A review of literature of previous studies conducted on teaching English as foreign language, with particular emphasis on total physical responses which are adopted in this research.

2- One group of slow learners has taught EFL by using total physical responses.

3- Observations have applied to experimental group. At the end of the experiment, to find out whether there are any statistically significant differences among the achievement of learners by using suitable statistical means.

\section{Section Two: Theoretical Background}

\subsection{Total physical response (TPR)}

It one of the methods which applied "the Comprehension Approach". It gives the importance to listening comprehension and later proceed to production. Language learning should start with listening the learner internalizes an extensive map of how the target language works, speaking will appear spontaneously ( Freeman, 2000:107).

This method developed by James Asher, he shares with the school of humanistic psychology a concern for the role of affective emotional factors in language learning. It involves game like movements reduces learners stress. He creates a positive mood in the learners, which facilitates learning processes ( Richards\& Rodgers;2001:73).

\subsection{Hypotheses of TPR}

TPR depended on hypotheses (Richards \& Rodgers;2001:74-75); that are:

1-there exists a specific innate bio-program for language learning. Accordingly, children develop listening competence before they develop the ability to speak, they can understand complex utterances that they cannot produce. When a foundation in listening comprehension has been established, speech evolves naturally.

2-Brain lateralization defines different learning functions in left and right brain hemispheres. TPR assumptions agree with Piaget's views that the child language leaner acquires through motor movement. That means this method directed to right- brain hemisphere. When a sufficient amount of right-hemisphere learning has taken place, the left one will be triggered to produce language.

3 -this method reduce the stress of learning other language because first language learning acquisition takes place in a stress-free environment. The TPR focuses on meaning according with movement rather than the language forms studied in the abstract.

This method hypothesized that acquisition is involved a kind of inductive process similar to that which occurs in native language. The process of acquisition would be automatic and unconscious. While learning is involved a formal process by which one consciously learns knowledge that is never becomes unconscious or automatic as acquisition. It is based on 'Monitor Hypothesis'(Sciarini\& Steinberg, 2006:152). 


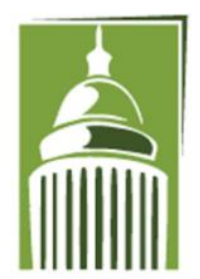

ARF

\section{Global Proceedings Repository \\ American Research Foundation}

ISSN 2476-017X

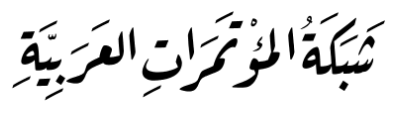

http://arab.kmshare.net/

Available online at http://proceedings.sriweb.org/akn/

\subsection{Theory of Language and Learning}

During the 1980s several scholars experimented various process-oriented approach to language teaching. One of them the Natural Approach was proposed by Terrel, it was later developed with combining of Monitor Model of language acquisition proposed by Krashen. Thus, it known as learning- centered method of teaching. It has drawn heavily from Chomskyan cognitive perspective on languagelearning and from the Hallidayan functional perspective on language use (Kumaravadivelu, 2008: 134-136). The aim of the method in early months of learning is aural comprehension. The name derives from the emphasis on the actions that learner has to make as he/ she is given simple commands (e.g. stand, sit, stop, ..)( Crystal,1997: 379).

TPR reflects a grammar- based view of language teaching. Asher sees a stimulus -response view as providing the learning theory underling language teaching pedagogy. Also, this method can be linked to trace theory of memory in psychology. Thus, the more intensively a memory connection is traced, the stronger the memory association will be recalled. Combined tracing activities such as verbal rehearsal accompanied by motor activity, increase the possibility of recall (Richards \& Rodgers;2001 : 73-74).

The method is heavily emphasized listening skill, and that a comprehension- before- production which is facilitated language acquisition particularly in the early stages. It is one of comprehension based methods, which is known during 1980s by James Asher. He was influenced by the implications he derived from research into first language acquisition (Nunan, 1999:205-207).

This method advocates a humanistic approach to language learning and teaching(Kumaravadivelu, 2008: 92). It is very much a 'natural -type method'. Only the target language is used in the classroom and meaning is derived from actual objects and situations (Sciarini\& Steinberg, 2006:147)

The method uses imperative to present the grammatical structures and vocabulary of foreign language. Thus, vocabulary and grammatical structures are emphasized over other language areas (Freeman,2000:115-118).

It helps learners link a new item with something known. This is useful for memorizing information in an orderly string (e.g. by sounds ,body movement, location on a paper or board..) this called "mnemonic Strategies". It does not foster deep associations but instead relat one thing to another in a simplistic, stimulus- response manner. It is the first step in learning vocabulary and grammar rules (Carter \&Nunan, 2002:167).

\subsection{The Role of Teacher in Teaching TPR}

Teachers provide opportunities for learning and give cognitive map that the learners will construct in their own minds. The teacher controls the language input, and gives feedback by correct little errors in the begging of learning ((Richards \& Rodgers;2001 : 74).

The teacher is the director of a class in which the learners are the actors (Asher 1977 cited Brown, 2000:107). 


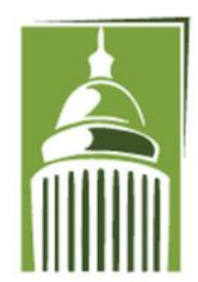

ARF

\section{Global Proceedings Repository \\ American Research Foundation}

ISSN 2476-017X

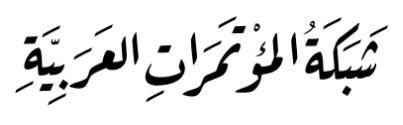

http://arab.kmshare.net/

Available online at http://proceedings.sriweb.org/akn/

TPR recommends the teacher activates their learners' motor skills through a commands sequence in which learners perform an action( Kumaravadivelu, 2008: 94).The teacher is director of all student behavior (Freeman, 2000:113).

\subsection{The Role of the Learners in TPR}

Learners have the primary roles of listener and performer. They listen and respond physically to commands given by the teacher. When they feel ready to speak, they are encouraged to do that (Richards \& Rodgers;2001 : 74). The students are imitators of nonverbal model. The learner usually after ten to twenty hours will be ready to speak (Freeman, 2000:113).

Andersen \& Lynch1988 say that the learners are 'active model builders' rather than 'tape recorders'. Rost (1990) suggests that learners are involved in hypothesis-testing and inferencing, not just decoding what is said (Ellis, 2003:39).

\subsection{Materials of Classroom}

The teacher demonstrates the meaning of the words and sentences by pointing to the objects and by acting on the commands foe all to see (Steinberg \&Sciarini, 2006: 148).

Imperative drills are the major classroom activity in TPR. They are used to elicit physical actions and activity of the learner (Ellis, 2003:39).

\subsection{Merits and Demerits of TPR}

One of the best merits of TPR that it gives an attention to the child listens before speaks the language and their listening is accompanied by physical responses. And it focuses on motor activity of right-brain function. Also, TPR has reduced anxiety in language classes (Browm, 2000:107).

TPR was developed to reduce the stress when studying foreign languages. Forcing the learner to speak create anxiety. Another way to relieve anxiety is to make language learning as enjoyable and fun as possible. Memory is activated through learner response. Foreign language instruction should address the right hemisphere of the brain, the part which controls nonverbal behavior (freeman, 2000: 111-114).

TPR reflects the idea that listening is an active skill rather than a passive skill (Ellis, 2003:39). Thus, it would seem sensible to make use of simple comprehension task with beginner learner, who cannot be expected to speak or written in foreign language until he/she has developed some competence (Ellis, 2003: 226).

The methods had limitations especially with advanced learners therefore it can be used as a type of classroom activity rather a method itself(Browm, 2000:107).Kumaravadivelu (2008: 94) called TPR as designer nonmethod because in his view deserved to be a method. It is no more than classroom procedures but the researcher disagree with him. The TPR is a method has driven from natural approach and humanistic language theory, it has techniques and producers in classroom but it has some limitation in elder stages. It is effective method in early beginning stage.Therefore the researcher has chosen this method for its suitability for the sample of research. Down syndrome learners imitate and monitor the action. 


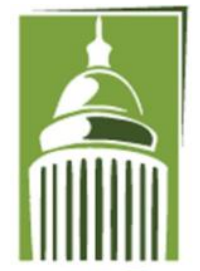

ARF

\section{Global Proceedings Repository \\ American Research Foundation}

ISSN 2476-017X

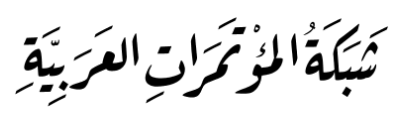

http://arab.kmshare.net/

Available online at http://proceedings.sriweb.org/akn/

This method is supported the listening tasks which provide the obvious starting point for low- proficiency learners. Simple listening tasks can be devised that can be performed with zero competence in the foreign language. It is carter the early stage of acquisition for some learner and the silent period of this stage (Ellis, 2003:38).

\section{Section Three: Procedures and Methodology}

\subsection{The Experimental Design}

The experiment design has been adopted to answer the aim of the research whether the teaching English through total physical response is effective or not.The research has adopted "repeated measures design" for these reasons:

This design can deal with the problem of non-randomization through a repeated measures design, in which all tasks are given to different individual in different times. Each participant's score at time 1 was compared with his/ her score at time 2 .....(Mackey \&Gass, 2005:152).

Treatment (TPR)... Observation 1...... Observation 2....... Observation3 .....

\section{2 Population and Sample Selection}

It has been taken Down syndrome children as slow learners. The sample of the research is (3) children at age of (3-5) years in Mama Mesoun Nursing and Kindergarten. (the number of the sample is only 3 children because the Iraqi policy in teaching do not allow to teach English until the accuracy of Arabic. Thus, most institutions did not agree to apply the research. The research is against the policy of Ministry of Education. All slow learner have special classes and institutions, they do not allow to accept in normal class. In these classes the teacher teaches them how to depend on themselves and they learn some numbers and word in Arabic that are necessary to keep them alive. The slow learners classified according their case as Down syndrome but they are kept in the same class whatever the age of the learner and their type are). The sample has matched in age, sex, case type. The entire sample is between 3-5 age, they are boys and they are mild type of syndrome.

\subsection{Instructional Material}

Ur (1996: 112-114) classified listening comprehension activities into four types according the response demanded of the learners; they are:

1- No overt response: the learners do not have to do anything in response to the listening; however, facial expression and body language often show if they are following the activity or not e.g (stories, songs, entertainment video,films...)

2- Short responses : in this type the learners show little action or performance with the responses; e.g( obeying instructions, ticking off items, true/ false, detecting mistakes, cloze, guessing, skimming, scanning, ..)

3- Long responses: the learners take long participate in this type; e.g (answer questions, note taking, translation, summarizing, gap filling).

4- Extended responses : it is a combined skills activities between listening and speaking like (problem solving and interpretation). 


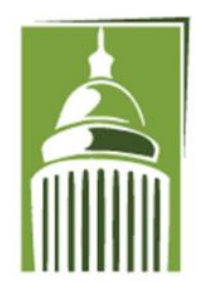

A R F

\section{Global Proceedings Repository \\ American Research Foundation}

ISSN 2476-017X

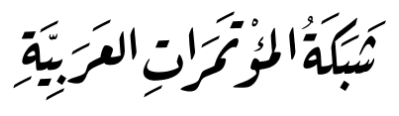

http://arab.kmshare.net/

Available online at http://proceedings.sriweb.org/akn/

The research has adopted the first two types of Ur (1996) activities (the activities with no response and activities with short responses).

The research has adopted (freeman:2000) instructions with some modifications. The first phase of a lesson is one of modeling. The teacher issues commands to a few learners, then pre forming the actions with them. In the second phase, these same students demonstrate that they can understand the commands by preforming them alone (Freeman, 2000:113).

Also, the researcher has adopted three models of listening of (Murcia, 2001:70-72), they are:

Model 1: listening and repeating : the learner listen and imitate and memorize

Model 2:task listening (listen- and- do) : feature activities that require a learner response pattern based on a listening -and using. The learners listen, then immediately do something with the information received.

Model 3 listening and answering: features a learner response pattern based on listening- and questionanswering model. The learner could answer the questions by one word( yes, no) or a sign from head or hand (agree, disagree).

Model 4 interactive listening: its discussion activity to develop aural/ oral skill. The research has neglected this model because it is difficult model for beginners and slow learners.

\subsection{Tools of the research}

The research has been used observation tool to collect the information and data of the research. As Genesee\& Upshur (1998: 77-79) show that observation is the basic to assess human skills and behaviors. Observation is an important aspect of foreign language research. Through observation teachers assess what students have and have not learned; they assess the effectiveness of particular teaching strategies and methods.

It refers to purposeful exanimation of teaching and learning events through systematic processes of data collection and analysis ( Carter\&Nunan, 2002:114).

In highly structured observations, the researcher often utilizes a dtalied checklist or rating scale. A structured observation can facilitate the recording of details such as when, where, and how often certain types of phenomena occur, allowing the researcher to compare behaviors through the experiment (Gass\& Mackey,2005: 175) .The sample of the research has observed 6 times after each month. They have observed according the rating sheet (Appendix 1) from 0-5. Also, the observations have recorded to allow the researcher score the same observation again after 1 week. Reliability refers to consistency, (Ibid: 128). Reliability is a matter of degree and is usually expressed by indices ranging from 0.0 to 1.00 . (Genesee \& Upshur, 1996:62). The reliability of first rating and second rating of the same observation is (89.1) by using recorded video camera. This indicates high reliably of the observations.

\subsection{Pilot Study}

The researcher has applied the study with one learner "the researcher's son". He is Down syndrome child. The pilot study has applied before the researcher can apply the real experiment on 3 slow learners .Because the policy of learning the slow learners, the government institutes cannotacceptteaching English Language.

\subsection{Construction and Administration of the Experiment}




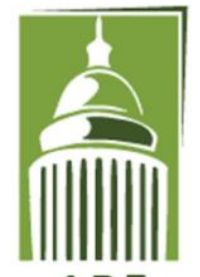

ARF

\section{Global Proceedings Repository \\ American Research Foundation}

ISSN 2476-017X

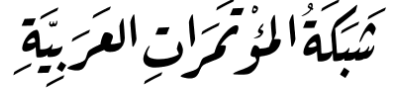

http://arab.kmshare.net/

Available online at http://proceedings.sriweb.org/akn/

The experiment has lastedone academic year at Mama Maeson Nursing and Kindergarten. The experiment has adopted for six months. The experiment group has taught English through lessons of total physical response.

The learners first have listened to nursing English songs during the fourth first lessons (nearly one month). The group of slow learners has taken one hour of learning English lesson daily for the whole period of experiment. The second month of teaching has showed the English letters, sounds of animals ..... Table 1 has showed the description of the lesson plan.

\section{Table (1) The Plan of Experiment}

\begin{tabular}{|c|c|c|}
\hline The lesson & The description of the lesson & \\
\hline $1,2,3,4$ & $\begin{array}{l}\text { Listening to English songs with } \\
\text { pointing }\end{array}$ & $\begin{array}{l}\text { English letters,parts of body, } \\
\text { things..) }\end{array}$ \\
\hline $5,6,7,8$ & $\begin{array}{l}\text { The teacher gives the learners } \\
\text { commands and do them (one or } \\
\text { two words) }\end{array}$ & Animals, sounds of animals \\
\hline $9,10,11,12$ & $\begin{array}{l}\text { The teacher gives the learners } \\
\text { commands and does them (more } \\
\text { than two words). }\end{array}$ & $\begin{array}{l}\text { Parts of body, colors, shapes, } \\
\text { things... }\end{array}$ \\
\hline $13,14,15,16$ & $\begin{array}{l}\text { The teacher gives the learners } \\
\text { more complexes commands and } \\
\text { does them. }\end{array}$ & Things in the class, pictures \\
\hline $17,18,19,20$ & $\begin{array}{l}\text { The teacher gives the learners the } \\
\text { commands that they have learned } \\
\text { by themselves. }\end{array}$ & $\begin{array}{l}\text { English letters, colors, } \\
\text { shapes,Animals, sounds of } \\
\text { animals }\end{array}$ \\
\hline $21,22,23,24$ & $\begin{array}{l}\text { The teacher gives the learners the } \\
\text { commands that they have learned } \\
\text { by themselves. }\end{array}$ & $\begin{array}{l}\text { Parts of body, colors, shapes, } \\
\text { things, things in the class, pictures }\end{array}$ \\
\hline
\end{tabular}

\subsection{Results}

The results observations have been analyzed, in order to determine whether there are significant difference among the scores achievement of sample .The results have showed that there are significant differences among the observation. This indicates that total physical response is effective methods for learning slow learners especially with Down syndrome learners. The sample has showed amazing development in English language. 


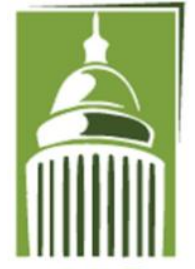

A R F
Global Proceedings Repository

American Research Foundation

ISSN 2476-017X

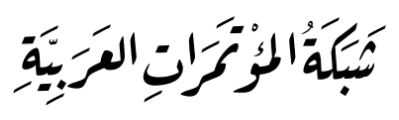

http://arab.kmshare.net/

Available online at http://proceedings.sriweb.org/akn/

\section{Table (2)}

\section{Scores of the Sample through the Experiment}

\begin{tabular}{|c|c|c|c|c|c|c|}
\hline $\begin{array}{c}\text { sampl } \\
\mathrm{e}\end{array}$ & $\begin{array}{c}\text { Observatio } \\
\mathrm{n} 1\end{array}$ & $\begin{array}{c}\text { Observatio } \\
\mathrm{n} 2\end{array}$ & $\begin{array}{c}\text { Observatio } \\
\mathrm{n} \mathrm{3}\end{array}$ & $\begin{array}{c}\text { Observatio } \\
\mathrm{n} \mathrm{4}\end{array}$ & $\begin{array}{c}\text { Observatio } \\
\mathrm{n} \mathrm{5}\end{array}$ & $\begin{array}{c}\text { Observatio } \\
\mathrm{n} \mathrm{6}\end{array}$ \\
\hline No.1 & $\mathbf{1}$ & $\mathbf{3}$ & $\mathbf{4}$ & $\mathbf{5}$ & $\mathbf{5}$ & $\mathbf{5}$ \\
\hline No.2 & $\mathbf{0}$ & $\mathbf{1}$ & $\mathbf{3}$ & $\mathbf{4}$ & $\mathbf{5}$ & $\mathbf{5}$ \\
\hline No.3 & $\mathbf{1}$ & $\mathbf{2}$ & $\mathbf{4}$ & $\mathbf{4}$ & $\mathbf{5}$ & $\mathbf{5}$ \\
\hline
\end{tabular}

The six observations are divided into two as the pre observations and post observations the $\mathrm{X}$ mean of the three observations are 1.05 and the standard deviations S.D are 0.235 while the $\mathrm{X}$ mean of post observations is 4.27 and S.D is 0.563 . That means there are significant differences between the pre and post observations under 0.05 significant levels and freedom degree 2 .

Table (2)

The $\mathrm{X}$ mean, standard deviations between the pre and post observations

\begin{tabular}{|l|l|l|l|l|l|l|}
\hline Variable & \multicolumn{2}{l|l|l|}{$\begin{array}{l}\text { Pre } \\
\text { observations }\end{array}$} & \multicolumn{2}{l|}{$\begin{array}{l}\text { Post } \\
\text { observation }\end{array}$} & $\begin{array}{l}\text { Calculated T } \\
\text { Value }\end{array}$ & $\begin{array}{l}\text { Statistical } \\
\text { significant }\end{array}$ \\
\hline \multirow{2}{*}{$\begin{array}{l}\text { Total physical } \\
\text { responses }\end{array}$} & $\mathrm{X}$ & $\mathrm{S} . \mathrm{D}$ & $\mathrm{X}$ & $\mathrm{S} . \mathrm{D}$ & 4.459 & Significant \\
\cline { 2 - 5 } & 1.05 & 0.235 & 4.27 & 0.563 & & \\
\hline
\end{tabular}

The observations of the sample through the whole experiment have showed interesting thing, that the whole sample of the research has acquired and produced English language (letters, colors, shapes, animals names..) instead of Arabic language. Thus, the English language has taken just one lesson daily. As, the results have shown teaching English language through total physical responses is effective methods in teaching EFL for Down syndrome learners and Iraqi slow learners.

\subsection{Conclusions}

The research has concluded that total physical response is suitable for the sample of the research and it has effect in acquiring English foreign language. Finally Down syndrome learners can learn English faster than the Arabic one. 


\section{Global Proceedings Repository \\ American Research Foundation}

ISSN 2476-017X

Available online at http://proceedings.sriweb.org/akn/

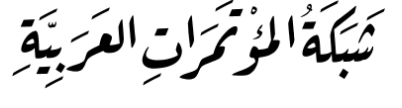

http://arab.kmshare.net/

ARF

\subsection{Recommendations and Suggestions}

The research is recommended TPR for teaching the learners specially Down syndrome children. Also, the results of the research has showed amazing development in acquiring English language therefore, the Iraqi Ministry of Education could be recommended to teach English to this neglecting sample and showed little respect with the slow learners who can learn and could be effective member of Iraqi society.

The research has suggested making other research on this sample Down syndrome because they are neglected from Special Education studies and TEFL. Also, the researchers might be investigated using other methods in teaching English for Down syndrome learners.

\section{Bibliography}

- $\quad$ Carter, R. \&Nunan, D. (2002) $4^{\text {th }}$ Ed. The Cambridge Guide to Teaching English to Speakers of Other Languages. U.K.: Camprdge University Press.

- Crystal, D. (1997) The Cambridge Encyclopedia of Language. $2^{\text {nd }}$. Great Britain: Cambridge University Press.

- Freeman, D. (2000) Techniques and Principles in Language Teaching. $2^{\text {nd }}$. Ed. UK: Oxford University Press.

- $\quad$ Genesee.F.\&Upshur, J. (1998) Classroom- based Evaluation in Second Language Education. U.S.A. :Cambridge University Press.

- Harley, T. (2008) The Psychology of Language from Data to Theory. $3^{\text {rd }}$. Edit. U.S.A.: Psychology Press.

- King, E. (2006). School Psychologist Files. Retrieved from http://www.schoolpsychologistfiles.com/slowLearnerFaq.html

- $\quad$ Kumaravadivelu, B. (2008) Understanding Language Teaching: from Method to Postmethod.New Jersey: Taylor \& Francis e-Library.

- Mackey, A. \&Gass, M. (2005) Second Language Reserch: Methodology and Design. U.S.A.:Lawrence Erlbaum Associates, Inc.

- $\quad$ Murcia, Marianne,C. (2001) Teaching English as a Second or Foreign Language. ${ }^{\text {rd }}$ Edit. U.S.A.: Heinle\&Henile.

- $\quad$ Nunan, D. Second Language Teaching \&Learning.U.S.A: Heline\&Helinle Publishers.

- Richards,J. \&Renandya, W. (2002) Methodology in Language Teaching: An Anthology of Current Practice. U.S.A.: Cambridge University Press.

- $\quad$ Richards, J. \& Rodgers, T. (2001) Approaches and Methods in Language Teaching. $2^{\text {nd }}$ Ed. Cambridge: Cambridge University Press.

- $\quad$ Sciarini, N. \& Steinberg, D. (2006) An Introduction to Psycholinguistics. $2^{\text {nd }}$. Edit. Great Britain: Pearson Longman.

- Williamson,J. \& Paul, J. (2012) The Slow Learner as Mediated Construct. Candian Journal of Disability Studies. CJDS (August).

- Ur, P. (1996) A Course in Language Teaching: Practice and Theory. Great Britain: Cambridge University Press. 


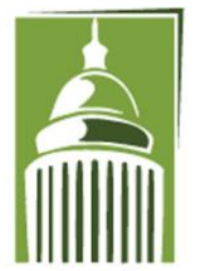

ARF
Global Proceedings Repository

American Research Foundation

ISSN 2476-017X

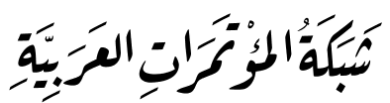

http://arab.kmshare.net/

Available online at http://proceedings.sriweb.org/akn/

\section{Appendix (1)}

Observation sheet for Rating the Sample Response

\begin{tabular}{|c|c|}
\hline Rating Scale & Item Response \\
\hline 5 & Excellent response with face , signs and oral repetition \\
\hline 4 & Appropriate response to audience/ situation/ instruction \\
\hline 3 & General appropriate response to audience/ situation/ instruction \\
\hline 2 & Somewhat appropriate response to audience/ situation/ instruction \\
\hline 1 & General inappropriate response to audience/ situation/ instruction \\
\hline 0 & No evidence that functions were preformed \\
\hline
\end{tabular}

